\title{
Natural Allies or Natural Enemies? \\ The Evolution of Participant Self-interest in Community-based Organizations
}

\author{
Michael Evans \\ Miami University
}

\begin{abstract}
Diverse families are increasingly turning to community-based organizations (CBOs) as a means to further support their children's education. In particular, CBOs appear to be effective at mobilizing families that diverge from the so-called norm in order to influence educational change. Research indicates that these organizations can have a positive impact on student outcomes but as independent actors, their relationships with schools remain complicated since they operate outside of school and district control. In order to better understand the dynamic relationships that emerge between educators and diverse families in CBOs, this paper uses an ethnographic case study approach to explore the initial motivations for participation of members in three different CBOs and the process that they use to determine their shared actions. The findings revealed that while individuals' initial involvement was primarily based on selfinterests, strong network ties, and perceived organizational effectiveness; the strategies and initiatives that were eventually implemented were more broadly defined and addressed larger systematic issues. In addition to offering diverse families an alternative means for engaging with schools, participants became committed to broader educational change making the potential for school and CBO partnerships more likely in the future.
\end{abstract}


Family involvement is widely accepted as a means for improving student outcomes across a variety of academic and social measures (Henderson \& Mapp, 2002). As a result many district, state, and federal policies now require schools to work on improving family involvement efforts. Most schools have responded to these policy demands by continuing to pursue or revise traditional family involvement practices that focus on transactional interactions with families. The school commits to educating a family's child according to district and state standards, while in exchange the family is asked to support and supplement the school's efforts by providing for the child's social, emotional, and academic needs. When families, in particular low-income and minority families, do not participate in traditional family involvement activities like volunteering in the classroom or attending parent teacher conferences, the common assumption is that they do not value education (Huss-Keeler, 1997, Lareau, 2000). However, research indicates that these same families may be reluctant, resistant, or unable to become more involved in schools based on legacies of oppression, memories of maltreatment, overtly inequitable school systems, and other barriers related to time, work demands, language and cultural dissonance (LawrenceLightfoot, 2003; Olivos, 2007 and Valdes, 1996). Moreover, the contributions that low-income and minority families do make to their children's education often go unrecognized by educators (de Carvhalho, 2001; Olivos, 2007). As a result families are increasingly seeking engagement opportunities that are independent of local schools (Rogers, 2006; Warren, 2005).

Research indicates that family involvement in community-based organizations (CBOs) helps historically marginalized populations more effectively engage in their child's education and that their efforts have a positive impact on student outcomes (Lopez, Kreider \& Coffman, 2005; Mediratta, Shah, \& McAlister, 2009). Despite the apparent benefits of CBO participation, some educators remain resistant to educational change efforts that originate from outside of the school (Crowson \& Boyd, 2001; Hong, 2011; Shirley \& Evans, 2007). In an effort to better understand the phenomenon of family engagement in CBOs and its potential impact on family and school power dynamics, the author used a qualitative case study approach to examine the motivations and experiences of participants in three different organizations. The findings suggest that diverse families in CBOs are motivated by a combination of self-interest, the influence of strong ties, and the desire to have an impact on their child's education. Through their participation in CBOs, family members experience an evolution in their understanding of how they can best support their child's education. Implications from this study include a consideration of how future collaborations between schools and CBOs might facilitate both improved family-school relations and impactful educational change.

\section{Educator Perspectives on the Complex Role of Power in Family and School Relations}

While research suggests that teachers and families generally have positive views about one another (Epstein, 1995), there is often an underlying tension in the relationship. Over eighty years ago, sociologist Willard Waller addressed this tension and described teachers and parents as "natural enemies" destined to come into conflict with one another because of their divergent interests (1932). While families and teachers may share a desire for a high quality education, the primary interest of the family is their own child and teachers must think about the needs of the entire class. According to Waller this inevitably leads to conflict and while his rhetoric may be somewhat overblown, research indicates that tensions between the home and school continue to persist (Lawrence-Lightfoot, 2003). 
In the 2005 MET Life survey of new teachers, respondents identified working with families and communities as their number one challenge (Markow \& Martin, 2005). While the struggles teachers encounter when trying to connect with families can in part attributed to limited training in this area (Evans, 2013), the occupational status of teachers also plays a role. In his classic 1975 book, Schoolteacher, Dan Lortie described teachers as having a "special, but shadowed social standing" in American society (p. 10). On the one hand teachers are admired for their important work with the next generation, yet at the same time the nature of their work is often misunderstood and they are rarely included in education policy-making efforts.

Historically teachers had more power within their own classrooms through pedagogical decisionmaking, but increasingly their professional autonomy is being stripped away as schools move toward more scripted curricula to address accountability demands related to high stakes testing and standardization (Ravitch, 2010). With many teachers feeling that their profession is under attack there is a tendency to become even further isolated from families and communities (Hargreaves, 2001). Perhaps this also explains why schools seek to tightly control interactions with families.

In their overview of parent involvement discourses, Baquedano-Lopez and colleagues identify a series of tropes including "parents as problems," "parents as first teachers," "parents as learners," "parents as partners," and "parents as choosers and consumers" (2013). In each of these tropes clear roles are established that correspond with school-based agendas and reinforce structural power relations. In these discourses the families of low-income and minority students are often framed as being deficient even when the rhetoric indicates the usage of "strengthbased" approaches (p. 152). We live in a time when federal policy promotes involvement strategies that are unlikely to foster collaboration. No Child Left Behind (NCLB) includes provisions for involvement and purports that the engagement of families is a central part of successful school reform (U.S. Department of Education, 2003). However, as Rogers (2006) notes, parent power is managed in NCLB through the narratives of accountability, choice, and involvement. These narratives emphasize the dissemination of data about school progress and student performance, the creation of "exit strategies" for students attending persistently lowperforming schools, and the use of parents as monitors of school effectiveness. Each of these narratives is based on a rationale that assumes educators will be motivated to improve practice unless there is a fear of losing students and/or funding. This policy feeds into traditional depictions of parent/teacher relationships by "pitting poor parents against unmotivated educators in a recalcitrant education system" (Rogers, 2006, p. 617). Examples of authentic participation where power is distributed and families are truly equal stakeholders remain rare, but research suggests that CBOs may play an important role in helping support these efforts (Schutz, 2006).

\section{Understanding Familial Motivations for Involvement}

As the positive impacts of family involvement in education became more apparent, researchers have become increasingly interested in understanding the rationale that informs school involvement decision-making. Hoover-Dempsey and Sander (1995) offer a three-part model for framing parental motivation. In this model parents' decisions to become involved are based on the following: 
(a) an active role construction for involvement (i.e., parents believe that they should be involved) and a positive sense of efficacy for helping the child learn; (b) perception of invitations to involvement from the school, teacher, and student; and (c) important elements of parents' life context that allow or encourage involvement (Hoover-Dempsey, et al, 2005, p. 106).

The three primary components of the model have been confirmed by numerous independent studies and expanded upon by scholars raising specific issues relating to culture, class, and race.

The related themes of role construction and parental efficacy entail beliefs regarding what a family members' role is in relation to schools and the perceived effectiveness of involvement activity. Several studies have indicated that familial roles in relation to school are defined differently depending on an individual's cultural background. For example, in Valdes' ethnography of Mexican immigrant parents, "American" parental involvement would be interpreted as an affront to the professionalism of a teacher in Mexico. In some parts of Mexico, the spheres of school and family are intentionally kept separate with the understanding that the autonomy of both families and teachers must be respected (Valdez, 1996). A study of Pakistani immigrants in the UK came to similar conclusions (Huss-Keeler, 1997). In this study teachers were concerned that their Pakistani students were not receiving adequate support at home because the teachers rarely saw the families. However, the Pakistani mothers in the study cared deeply about their children's education. According to the participants, "being a 'good parent' in Pakistani terms was not to go to school, but to do their duty with their children in the home" (p. 179).

Additional studies focused on social class have indicated that occupational status also influences parental role construction. Lareau (2000) observes that school is often understood as the child's job, and thus approaches to school frequently parallel parents' occupational status. In families where "white collar" work is the norm, students and parents are more accustomed to jobs that may require additional time at home. Thus, homework or projects that extend beyond the school day are expected on a regular basis. In homes where the family may have a more "blue collar" background, work life and home life are kept separate. Families may be more resistant to engaging with work beyond the traditional school day. In this same study, Lareau also found that educational status shaped a parent's perception of their ability to help with school related activities. Parents who have dropped out of school may feel unqualified and thus reluctant to help their child. Other obstacles include time, finances, and language barriers ( $\mathrm{Li}$, 2010). Working parents may hold multiple jobs or have inflexible schedules making it impossible to attend school activities during the day (Lareau, 2000) and educators are often unwilling to hold meetings in the late evening (Payne, 2008). Closely linked to this is the need to work long hours or multiple jobs to provide for families and the tremendous psychic and physical demands that this places on families.

Hoover-Dempsey and colleagues also discuss the important role of invitations for participation (2005). They identify multiple avenues for invitations including general school culture or climate, direct invitations from teachers, and communication with the child. As this relates to diverse families, schools have made some progress at becoming more culturally inclusive, but most educators continue to operate under a limited perspective of what constitutes acceptable parental involvement and this influences both the types of invitations that are made and whether they are extended at all (Auerbach, 2002; Boethel, 2003; Lareau \& Horvat, 1999). For immigrant populations students are often called upon to be the primary point of contact 
between the school and family, placing additional pressure on the child and complicating family power dynamics (Phelan, Davidson \& Cao, 1991; Suarez-Orozco \& Suarez-Orozco, 2001).

Linguistic barriers prevent many families from effectively communicating or participating in the education of their children (Zarate, 2007). Finally, as previously mentioned, some families simply feel unwelcome because of their own personal experiences with schools (LawrenceLightfoot, 2003).

\section{Family Engagement through Participation in Community-based Organizations}

The Hoover-Dempsey model provides insight on the motivations for family involvement and helps frame how some families have been systematically marginalized by a combination of school policies and social norms. Thus, the dramatic rise of participation in CBOs and their ability to mobilize diverse families is a compelling new model for family engagement (Mediratta, et al., 2009). CBOs offer alternative settings for engagement and have diverse organizational structures based on models of community organizing, political action committees, advocacy organizations or some hybrid combination of the three (Evans, Newman, \& Winton, 2012). CBOs have the potential to draw on the strengths of diverse families and facilitate the growth of stronger relationships with schools and other educational stakeholders (Lawson \& Almeda-Lawson, 2012; Lopez, et al., 2005). While a number of excellent works have chronicled and analyzed the work of CBOs at the macro-level there is more limited research on the experience of individual participants (Lopez, et al., 2005; Oakes \& Rogers, 2006; Shirley, 1997; Warren, 2001). The emergence of CBOs as new contexts for engagement coupled with their explicit focus on the generation of political power, warrants a closer analysis of what draws families into these organizations and the potential implications for family and school partnerships. The research questions are as follows:

Research Question 1: What motivates families to become involved in community-based organizations working on education issues?

Research Question 2: How do participants contribute to agenda setting within community-based organizations?

\section{Methodology}

The research that informs this article was conducted between 2006 and 2008. The researcher used an ethnographic multiple-case study approach to examine the internal workings of three Massachusetts based CBOs engaged in education issues. Data for the case studies included interviews, observations of various CBO activities, and the collection and analysis of documentation (Miles \& Huberman, 1994). The three case study sites are: United Interfaith Action (New Bedford, MA), Jamaica Plain Parent Organizing Group (Boston, MA), and Stand for Children (Lexington, MA). All three of the case sites are located in Massachusetts, a decision in part based on convenience, but one that also facilitated cross-case analysis, with each CBO operating under some shared governmental circumstances. For example, the school districts in each site all had to address the same standardized tests (MCAS) and state curricular frameworks. They were also governed by the same set of laws and impacted by the same policies, such as the state education funding formula. At the same time the three communities differ in size, demographics, history, and their economic situations. The following is a brief description of the three case study sites. 


\section{Case Descriptions}

\section{United Interfaith Action.}

United Interfaith Action (UIA) is a faith-based organization, affiliated with the national organization People Improving Communities through Organizing (PICO). Based in the southeastern Massachusetts cities of New Bedford and Fall River, at the time of the study UIA consisted of twenty religious institutions. The membership of UIA is ethnically diverse and the majority of the members come from working class backgrounds. Since 1996 UIA has been working in New Bedford and Fall River around issues like community safety, immigration, economic development, and after-school programming for youth. UIA was new to the field of education organizing at the start of this study and during the data collection period its members were still in the process of learning how to navigate local school politics.

\section{Jamaica Plain Parent Organizing Project.}

The Jamaica Plain Parent Organizing Project (JP-POP) is part of City Life/Vida Urbana (CLVU), a neighborhood organization founded in 1973 with a primary emphasis on tenant rights and housing issues. The membership of JP-POP consists of low-income, Spanish speaking parents in the Jamaica Plain neighborhood of Boston. The group's affiliation with the multiissue group CLVU and connections with the citywide Boston Parent Organizing Network (BPON) provided additional network resources to assist in the pursuit of organizational goals. Since 2002, JP-POP has organized actions in support of bilingual education, the creation of family community outreach coordinator positions, special education policy, and school budget increases.

\section{Stand for Children, Lexington, Massachusetts.}

The third organization is a grassroots advocacy group and was selected because its membership represents a class of individuals (predominantly white, middle to upper-middle class) who are just starting to utilize community organizing strategies to lobby on the behalf of children (Abramson, 1992). At the time of this study Stand for Children had an official presence in four states, but has since expanded to eleven. This study focuses on the Lexington chapter of Stand for Children, the first of its kind in Massachusetts with a membership of close to 200. Despite being a relative newcomer on the local political scene, the chapter quickly contributed to a number of local political victories, including successful tax override campaigns in 2004 and 2007, and the district wide adoption of the Environmental Protection Agency's "Tools for Schools" maintenance program for improving indoor air quality. While middle class populations have been an important part of grassroots peace and environmental movements (Rose, 2000), their membership in education reform has been limited. This is perhaps explained by higher levels of involvement among the middle class families in traditional family/school activities and general satisfaction with high performing schools in affluent neighborhoods.

\section{Data Sources}

Because the parental involvement literature is used to help frame this study participants were sought who either had children in the public schools or children who were recent graduates. 
Four interviews were held (one in Lexington and three in New Bedford) with individuals who did not have children. These interviews were conducted to obtain additional background information about the organizations or details regarding specific actions. The purposive sampling techniques described by Stake were utilized to help select the participants at each research site. In this approach:

The researcher discusses these characteristics (attributes of interest) with informants, gets recommendations, visits several homes, and gets attribute data. The choices are made, assuring variety, but not necessarily representativeness, without strong argument for typicality, again weighted by considerations of access and even by hospitality, for the time is short and perhaps too little can be learned from inhospitable participants (Stake, 2002, pp., p. 447)

In each case study the community organizer played a significant role in providing access to the organization's activities and helping set up individual interviews. However, the participants themselves were also helpful resources, contributing suggestions for people to interview and helping create a snowball sample of organization members. Additional information regarding interviews and general membership is provided in Table 1.

\section{Table 1. Interview, Observations, and Estimated Number of Members}

\begin{tabular}{|l|l|l|l|l|l|l|}
\hline & $\begin{array}{l}\text { Interviews } \\
\text { with CBO } \\
\text { organizers }\end{array}$ & $\begin{array}{l}\text { Interviews } \\
\text { with CBO } \\
\text { members }\end{array}$ & $\begin{array}{l}\text { Observations } \\
\text { of CBO } \\
\text { activities }\end{array}$ & $\begin{array}{l}\text { Total \# } \\
\text { of Core } \\
\text { Members }\end{array}$ & $\begin{array}{l}\text { Estimated } \\
\text { \# of Total } \\
\text { Members }\end{array}$ & $\begin{array}{l}\text { Est. } \\
\text { Turnout } \\
\text { Potential } \\
\text { for large } \\
\text { actions }\end{array}$ \\
\hline UIA & 1 & 8 & 12 & $12-15$ & 50 & 1,000 \\
\hline JP-POP & 1 & 8 & 8 & $10-12$ & $50-60$ & 200 \\
\hline STAND & 2 & 7 & 10 & $10-12$ & 200 & 1,200 \\
\hline
\end{tabular}

The interview protocol was based on a combination of questions generated from a review of the existing literature on education organizing, community organizing more broadly defined, and educational change. In addition informal interviews were conducted with members at events. In total, thirty formal observations were conducted, including attendance at rallies, meetings with school or civic officials, and planning or organizational meetings. Finally, documents related to the CBOs were also an important source of data. Meeting agendas, training manuals, working outlines of upcoming events, testimonial scripts, websites, brochures, newspaper clippings and other organizational literature were all collected, coded and analyzed. 


\section{Data Analysis}

Data analysis was an iterative process that began during data collection and was continued through the completion of this study. Merriam describes this process as, "making sense out of data... consolidating, reducing, and interpreting what people have said and what the researcher has seen and read-it is the process of making meaning" (Merriam, 1998, p. 178). Ideas about possible categories and themes were identified and included in field notes and memos (Rossman \& Rallis, 2003). Based on these ideas additional literature was reviewed, shaping both future data collection and analysis. The data sources were triangulated and an open coding process was used to identify dominant themes and construct a "holistic understanding" of the case (Corbin \& Strauss, 2008; Mathison, 1988).

\section{Findings}

\section{Motivations for Involvement in CBOs}

Despite the CBOs being located in very different geographic areas and having significantly different membership populations, three interrelated motivations for participation were identified that cut across participants in each of the case studies: self-interest, strong network ties, and perceived organizational effectiveness.

\section{Self-interest.}

Narrowly defined self-interests were frequently cited as the most important motivational factor for initial CBO participation. By narrowly defined, the self-interests described by the participants were focused on their own immediate needs or the needs of their children. Of course, these self-interests varied by individual and were in part a by-product of the larger environmental context. For example in New Bedford, where UIA had been addressing issues of community violence and public safety for almost a decade, participants cited occasions of bullying and intimidation that had impacted their own families. One new member testified, "My daughter in junior high school was involved in a fight and I felt really bad for her. The aggressor wanted to fight her and my daughter didn't want to fight, so all of the kids were circling around her and calling her a 'baby,' so that kinda stuck with me." This type of specific personal experience was typical among the participants. These concerns were identified by the CBOs through a process of one-on-one meetings that were either coordinated by the lead organizer or by other CBO members.

Similarly members of JP-POP spoke frequently about the difficulties that they faced navigating the special education system as bicultural parents. In fact, it was not uncommon for family members to initially learn about JP-POP as they were in the midst of trying to develop an Individualized Education Plan (IEP) for their child. JP-POP offered classes focused on the rights of parents with children in special education and more informal group support to parents who were feeling intimated by the IEP process (Evans \& Shirley, 2008).

On occasion larger social disruptions in the community were linked to the emergence of individual self-interests that brought families into CBOs . Significant events or policies that challenged social norms within the community and impacted families directly influenced participation. In 2004, this came in the form of a failed tax override campaign for members of 
Stand for Children. As one participant remarked, "It was one thing to read about an issue in the paper, but it was something else when your child was in tears because their favorite teacher had been downsized." These types of events brought latent self-interests to the forefront. A similar example was the 2002 ballot campaign in Massachusetts that sought to eliminate bilingual education. In the aftermath, English learners were suddenly feeling lost at school and parents came to JP-POP looking for support and a way to advocate for their rights. Even for those parents who were already involved in schools, these issues were beyond what they could influence as individuals at the classroom or building level. For some this was a wake-up call about the limitations of traditional forms of involvement:

Quite honestly, for having done PTA work and classroom involvement for awhile and then watching the schools deteriorate after the loss of the override, I sort of poo-pooed that kind of work, and said, "Oh my god, I can't believe that I have been putting my time in there when I should have been really watching the shop because look what's happening." It was an irrational reaction perhaps, but it was my reaction. I thought, "Oh my god, I've got to get involved in political advocacy because Rome is burning! (Stand for Children Member)

Within the communities these episodes of social disruption became galvanizing events and opportunities for CBO leaders to mobilize people around their shared self-interests.

While self-interests were the primary sources of motivation for joining a $\mathrm{CBO}$, personal relationships also played a critical role in creating awareness of CBO opportunities. As the interviews progressed dense networks of families, friends, neighbors, and educators emerged. This is consistent with research on the value of strong network ties for the initial growth of social movements (McAdam \& Paulsen, 1993). While eventually weak ties become important in order to help spread information and action (Granovetter, 1973), strong ties help to solidify initial commitments and spur action. Participants in all of the groups reported feeling "honored" and "flattered" that friends or acquaintances felt that they could contribute to the group. Personal relationships were essential for the recruiting people who were "on the fence." The prospect of becoming more politically engaged within the community intimidated some members. One UIA member stated, "it seemed like it might be a little out of my league." But her friends gently pressured her to continue to attend and learn more about the process. Others described grabbing friends who tried to sneak out the back door. On Stand leader told her friend, "Listen, I know that some of this sounds strange, but give it a chance. This is a group that can really do some good work." These familial and neighborly endorsements served as both an invitation and provided a foundation of trust. Trust is an important element for effective school reform and relationships help build the social capital that is necessary for the effective navigation of education politics (Bryk \& Schneider, 2002; Shirley, 1997; Warren, 2001).

Even in relationships where the participants did not previously know one another, there was a sense of trust that other CBO members desired similar things. In UIA there was a powerful faith-based foundation, as one new member commented, "It was so helpful and it was that sort of feeling where even though you just met, you felt like you knew each other for years and years and years... there was a familiarity with one another." For JP-POP members there was 
a common bond in that members shared the unique experience of being both bicultural parents and the guardian of a child with special needs. "It is just nice to be around other people who know what you are going through," remarked one mother. In fact, this sense of comfort was so strong that members wanted to share it with others in need. One JP-POP member described meeting a neighborhood woman while waiting in the health clinic, "she really felt overwhelmed and I let her know that with time it is going to get better. I know how she feels. I feel like we can help her so I am trying to get her to go to the JP-POP meetings." Also worth noting, is that two JP-POP participants received referrals to the organization from their children's teachers. According to the organizer this was not uncommon. In recognition of the struggles that parents were having navigating the special education system, some teachers cited JP-POP as a potential quality resource.

\section{Perceived effectiveness.}

Finally, success begat success within the three cases. Leaders in CBOs frequently discuss the importance of identifying winnable issues. The rationale being that initial success can help empower individuals to further invest themselves in the organization and it can sustain groups if they encounter struggles while addressing larger and more complex issues. For the participants in this study this was also true. Media coverage and word of mouth about CBO victories often piqued new member interest. While they still might not actively seek out the organization, when they were approached they were far more receptive to the invitation because of the CBOs' bourgeoning reputations. In other instances, small groups of participants actively

sought out the CBOs. These individuals believed that the CBOs possessed a skill set that would enable them to achieve their goals. As one Stand member said, "We were all feeling sort of desperate. And I wanted to get organized, but I didn't know how to run a meeting. You know some of the granular elements of process that I didn't expect or know." It was evident to members that traditional school or bureaucratic channels were not always effective for influencing education policy, so the CBOs provided an alternative and efficacious means for these individuals to become involved.

Individuals want to feel that their actions are making a difference and there were numerous tangible victories, both in terms of broader organizational goals and smaller personal "wins" throughout the organizing process. As one UIA mother commented, "I have lived in New Bedford for my entire life, but until I joined UIA I had never met a single city politician. Now I am sitting down with the mayor and the chief of police and they actually listen to what I have to say!" Efficacy even played a role for those participants who were already involved in more traditional forms of family involvement. In some instances they called into question their prior involvement. As one active Stand mother declared, 'I'm not going to do the bake sale. I need to be out holding signs!"

\section{Collective Agenda Setting in CBOs}

While self-interests, strong ties, and perceived effectiveness brought CBO participants together, the resulting strategies and objectives were often much broader in scope. Through dialogue and ongoing research organizing participants began to understand that addressing their self-interests was linked to the transformation of broader social issues. For example, UIA's 
initial campaign was focused on the implementation of a Conflict Resolution Education (CRE) program in the New Bedford schools. The CRE program was itself a byproduct of shared selfinterests as individuals seeking to resolve personal experiences of community violence identified this program as one possible solution. As UIA pushed the CRE agenda forward they began to recognize that there were broader educational and social issues that also needed to be addressed. Unemployment rates in the region were the highest in the state and many believed that the local schools' expectations for its students were too low. While UIA continued to work on CRE they also developed a community compact with the following goals:

- Bringing the graduation rate up 18 percent and increasing college attendance by 25 percent in five years.

- Improving parent-school relationships

- Developing a strategy for paying for the improvements

- Creating a plan for accountability

While somewhat open ended, these goals were oriented toward community transformation and sought to benefit all of the children in New Bedford. In recognition that they were working with "street level bureaucrats" UIA even adapted their campaign to include an internal organizational commitment to the youth of the city. They wanted to demonstrate that they were also committed to taking action and arranged for volunteer sign-up tables for programs like Big Brothers and Big Sisters at large local actions.

In JP-POP members recognized that there were some severe communication gaps between families and the district. While they continued to help individual members navigate the BPS system, they also began to work with the Boston Parent Organizing Network (BPON) to develop a campaign to fund Family and Community Outreach Coordinators (FCOCs). These district employees would be responsible for helping both teachers and families more effectively communicate with one another (Evans \& Shirley, 2008). During a final budget meeting, Interim Superintendent Contampasis commented on the school board's decision to increase funding, "We have had the benefit of three public hearings on the budget. I am grateful to those parents, teachers, and other members of the community who took the time to attend the hearings and provide testimony. The one consistent theme that we have heard throughout these hearings was the effectiveness of and the need for additional Family and Community Outreach Coordinators." The JP-POP members were elated. According to one member, "this was our most important victory to date. This will benefit all of the children in the community."

Finally, even in the more affluent Lexington community where parents are frequently stereotyped as being self-involved, there was a significant shift in the group's organizing priorities. While members initially joined to address local funding challenges that impacted their children, a majority of the members began to partner with other communities to work at the state level on reforming the school funding formula. It is a change they hoped would have a significant impact on children throughout the state. As one mother observed:

Frankly, we are pretty darn lucky here in Lexington. It's not to say that we don't want better for ourselves and our kids and it's not to say that it's perfect but I 
think that we have a responsibility not just to our own kids but to the kids across the state. Really a rising tide raises all ships. If we can work for a better educational system and better funding for the educational system across the state it would just be better for everyone.

This was a sentiment that was observed across all three of the case studies and it was not presented in moralistic or altruistic terms. Tocqueville refers to this as self-interest rightly understood. He writes, "American moralists do not claim that one must sacrifice oneself for one's fellows because it is a fine thing to do but they are bold enough to say that such sacrifices are as necessary to the man who makes them as to those gaining from them" (Tocqueville, 1835/2003, p. 610).

Figure 1: Evolution of CBO Organizing Campaigns: From initial motivations to systemic change efforts

UIA

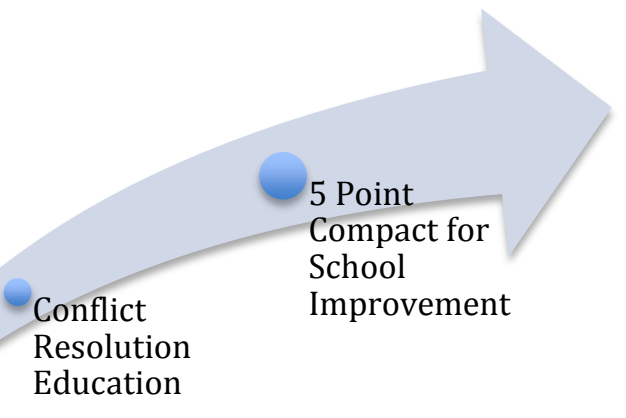

\section{JP-POP}

Family

Community

Outreach

Special

Coordinator

Education

Services for

Position

\section{Stand for Children}

Statewide

School Funding

Proposition 2

$1 / 2$ Tax

Override 
How did this transformation take place? The CBOs created the setting for education dialogues, which eventually led to the evolution of each CBOs objectives. Through open communication and the participation of diverse stakeholders innovative policy solutions began to emerge. This type of transformation is not atypical among groups or organizations attempting to practice versions of participatory democracy. Poletta (2002) offers a nuanced perspective in her description of CBOs:

Underpinning this scenario... is a view of people's individual interests as clear and fixed and of collective agendas as a kind of Venn diagram of intersecting interests. Group interests are brokered from individual ones. The alternative, however, is that both individual and common interests may emerge from discussion and deliberation - not through a process of negotiation (which assumes that interests are fixed) but through a process of self- and collective discovery. Decisionmaking on this model... is aimed not only at matching means to ends but also at scrutinizing and redefining ends (Polletta, 2002, p. 186)

She notes that organizers might not embrace this description for two reasons. First, it could be interpreted that people may not know their personal interests and second, this approach may not be viewed as being expeditious. However, based on observations from the case studies, the idea that definitions of self-interest evolve through participation CBOs is an accurate description.

\section{Discussion and Implications}

The motivations that were identified among the CBO participants in this study were quite similar to factors previously identified in the Hoover-Dempsey model. However, the findings also build upon this research in some intriguing ways. First, discussions in the Hoover-Dempsey model regarding how life contexts can impact involvement are often focused on personal or social resources. This study highlights that in addition to resource availability important events or experiences can also lead to eruptions of engagement. These life events can be powerful enough that families may be motivated to seek out new resources or solutions that will help them to navigate engagement obstacles. Second, invitations for engagement have historically originated from schools, teachers or students, but in CBOs other family members, neighbors, and friends can also become sources for recruitment. The value of invitations based on strong ties is that a sense of trust and commitment is already embedded in these relationships. Finally, Hoover-Dempsey emphasizes the importance of a positive sense of efficacy. Families yearn to know that their efforts are making a difference and CBOs demonstrate a proven track record of tangible outcomes that appeal to diverse families.

Many of the barriers for engagement are structural in nature and CBOs offer diverse families an effective means for achieving more authentic participation (Schultz, 2006). CBO agendas such as implementing a new curriculum proposal (UIA), the creation of new positions in the school system (JP-POP), and advocating in the community for increased funding and legislative reforms (Stand for Children) are all issues that have historically not been effectively addressed through school based forums like the PTA (Schultz, 2006). These goals directly challenge the notion that families are only concerned about the school experiences of their own 
child. Far from being "natural enemies," the work of these CBOs would seem to indicate that they have the potential to become "natural allies." At first glance potential collaborations between schools and CBOs would appear to be complicated at best. Contentious tactics utilized by some CBOs may distance public employees like teachers and administrators who are not elected officials and who are often working under challenging circumstances (e.g. high stakes testing and limited funding) (Evans, 2009; Fabricant, 2010; Shirley, 1997). Furthermore, the emphasis on self-interest as a central organizing principle feeds into educator assumptions regarding the inherent selfishness of parents and families (Crowson \& Boyd, 2001). Yet for marginalized families, where dissonance already exists with family and school engagement, CBOs provide opportunities for authentic participation in education decision-making. Participants may be motivated by self-interest and the specific needs of their child; however, they also demonstrate collaborative potential by the simple act of joining a social organization. Saul Alinsky, widely considered the "founding father" of community organizing writes, "Political realists see the world as it is: an arena of power politics moved primarily by perceived immediate self-interests, where morality is rhetorical rationale for expedient action and selfinterest." For educators this type of statement might confirm their worst fears of parental selfishness, yet Alinsky's definition is far more nuanced than it is often presented. He also states:

The overall case must be of larger dimensions than that of self-interest narrowly defined; it must be large enough to include and provide for the shifting dimensions of self-interest. You may appeal to one self-interest to get me to the battlefront to fight; but once I am there, my prime self-interest becomes to stay alive, and if we are victorious my self-interest may, and usually does, dictate entirely unexpected goals rather than those I had before the war (Alinsky, 1971, p. $55)$.

Alinksy recognizes that interests are not stagnant, but rather shift and evolve depending upon context. Educators who are reluctant to collaborate with community organizations because they operate independently of a school's agenda should reconsider the value that this type of relationship might bring. CBOs are not beholden to bureaucratic policies and have the flexibility to advocate for innovative and transformative reforms (Shirley \& Evans, 2007). They can provide insights into the desires of the community and their process is oriented toward the identification of broader social interests. These are the types of allies that can work with schools toward sustainable change. Of course a move toward authentic collaboration will require school leaders to reexamine preconceived notions regarding what constitutes family involvement, but this will benefit both students and teachers. As one JP-POP mother observed:

They (the teachers) feel like they are under attack. We aren't attacking! I know she will be accountable if she has the proper resources. And we will fight for that resource. If she worked together with me, I can give her what she needs. Like for example, if a teacher needs a computer program to help a child and I know she can do a better job to teach that child if she got this. I need to fight for the child. They need to understand me that I don't want to fight with the teacher. I go and fight against the system. The system needs to provide what the child and the teacher needs in the classroom. 
By reframing families and CBOs as allies educators may need to relinquish some vestiges of power, but perhaps in return a new and more efficacious form of power will be created. At the same time CBOs must do their part to build relationships with teachers and administrators who are struggling to work under the same oppressive conditions. It will take time and effort to establish meaningful relationships with educators whose sense of professionalism has been under attack, but as Fabricant notes, "individual CBOs do not have the capacity to wage successful campaigns for educational change systemwide" (p. 48). In summary, CBOs and educators need one another. Only through collaboration do schools and CBOs have the capacity to address the larger structural issues that adversely impact public education.

\section{Conclusion}

Diverse families who fail to meet the family involvement expectations of schools are often criticized for not valuing education. However, research has demonstrated that these families are often engaged in their children's education in ways that are simply not valued or recognized by schools. One of these alternative forms of engagement is participation in CBOs. CBOs present a challenge for some educators who are accustomed to more school-based involvement activities, but as examples of $\mathrm{CBO}$ effectiveness in relation to positive student outcomes continue to emerge it is likely that more teachers and administrators will want to consider how they might work with these organizations. Building on the work of Hoover-Dempsey and colleagues, this study explored the initial motivations for participation of diverse families in three different $\mathrm{CBOs}$ and how they came to determine their change strategies. The findings revealed that while individuals' initial involvement was primarily based on self-interests, strong network ties, and perceived organizational effectiveness; the resulting strategies and initiatives were more broadly defined and addressed larger systematic issues. CBOs are receptive to the needs of diverse families, perhaps in a way that schools cannot or will not be able to achieve on their own. Families who have felt excluded from participating in their child's education may be more inclined to trust and work with organizations that serve individuals with similar experiences. For teachers and other educational leaders this raises the possibility of working with CBOs as natural allies in the quest for school improvement. Clearly CBOs have the potential to empower families to engage in education policy and transform public education in a manner that schools cannot achieve on their own. 


\section{References}

Abramson, P. R. (1992). A case for case studies. Thousand Oaks, CA: Sage.

Alinsky, S. (1971). Rules for radicals. New York: Vintage.

Auerbach, S. (2002). Why do they give the good classes to some and not to others? Latino parent narratives of struggle in a college access program. Teachers College Record, 104(7), 1360-1392.

Baquedana-Lopez, P., Alexander, R. A., \& Hernandez, S. J. (2013). Equity issues in parental and community involvement in schools: What teacher educators need to know. Review of Research in Education, 37, 149-182.

Boethel, M. (2003). Diversity: School, family and community connections. Austin, TX: National Center for Family and Community Connections.

Bryk, A. S. \& Schneider, B. (2002). Trust in schools: A core resource for improvement. New York: Russell Sage Foundation.

Corbin, J., \& Strauss, A. (Eds.). (2008). Basics of qualitative research: Techniques and procedures for developing grounded theory. Thousand Oaks, CA: Sage Publications.

Crowson, R. L. \& Boyd, W. L. (2001). The new role of community development in education reform. Peabody Journal of Education, 76(20), 9-29.

de Carvhalho, M. P. (2001). Rethinking family-school relations: A critique of parental involvement in schooling. Mahwah, NJ: Lawrence Erlbaum Associates.

Epstein, J. (1995). School, family, and community partnerships - caring for the children we share. In School, Family, and Community Partnerships: Preparing Educators and Improving Schools (pp. 401-425). Boulder, CO: Westview.

Evans, M. P. (2009). Inside education organizing: Learning to work for educational change. Dissertation Abstracts International, AAT 3349521.

Evans, M.P. (2013). Educating pre-service teachers for family, school, and community engagement. Teaching Education. 24(2), 123-133.

Evans, M. P., Newman, A. \& Winton, S. (2012, April). Not your mother's PTA: Organizational hybridity in community based education reform groups. Paper presented at the annual meeting of the American Educational Research Association, Vancouver, BC.

Evans, M. P. \& Shirley, D. (2008). The development of collective moral leadership among parents through education organizing. New Directions for Youth Development, 116, 7791. 
Fabricant, M. B. (2010). Organizing for educational justice: The campaign for public school reform in the South Bronx. Minneapolis, MN: University of Minnesota Press.

Granovetter, M. (1973). The strength of weak ties. The American Journal of Sociology, 78(6), 1360-1380.

Hargreaves, A. (2001). Beyond anxiety and nostalgia. Phi Delta Kappan, 82(5),128-135.

Hong, S. (2011). A cord of three strands: A new approach to parent engagement in schools. Cambridge, MA: Harvard Education Press.

Henderson, A. T., \& Mapp, K. L. (2002). A new wave of evidence: The impact of school, family, and community connections on student achievement. Austin, TX: Southwest Educational Development Laboratory.

Hoover-Dempsey, K.V., Walker, J.M.T., Sander, H.M., Whetsel, D., Green, C.L., Wilkins, A.S., \& Closson, K.E. (2005). Why do parents become involved? Research findings and implications. Elementary School Journal, 106(2), 105-130.

Hoover-Dempsey, K., \& Sander, H. (1995). Parental involvement in children's education: Why does it make a difference. The Teachers College Record, 97(2), 310-331.

Huss-Keeler, R. L. (1997). Teacher perception of ethnic and linguistic minority parental involvement and its relationships to children's language and literacy learning: A case study. Teaching and Teacher Education, 13(2), 171-182.

Lareau, A. \& Horvat, E. M. (1999). Moments of social inclusion and exclusion: Race, class, and cultural capital in family-school relations. Sociology of Education, 72(1), 37-54.

Lareau, A. (2000). Home Advantage. Lanham, MD: Rowman \& Littlefield

Lawson, M. \& Almeda-Lawson, T. (2012). A case study of school-linked, collective parent engagement. American Educational Research Journal, 49(4), 651-684.

Lawrence-Lightfoot, S. (2003). The essential conversation. New York: Random House Publishing.

Li, G. (2010). Social class, culture, and 'good parenting': Voices of low-SES families. In Marsh, M. \& Turner-Vorbeck, T. (Eds.), (Mis)Understanding families: Learning from real families in our schools (pp. 162-178). New York, NY: Teachers College Press.

Lopez, M.E., Kreider, H. \& Coffman, J. (2005). Intermediary organizations as capacity builders in family educational involvement. Urban Education, 40(1), 78-105.

Lortie, D. C. (1975). Schoolteacher: A sociological study (2nd ed.). Chicago, IL: The University of Chicago Press. 
Markow, D. \& Martin, S. (2005). The MetLife survey of the American teacher: Collaborating for student success. New York, NY: MetLife, Inc.

Mathison, S. (1988). Why triangulation? Educational Researcher, 17, 13-17.

McAdam, D. \& Paulsen, R. (1993). Specifying the relationship between social ties and activism. American Journal of Sociology, 99(3), 640-667.

Mediratta, K., Shah, S. \& McAlister, S. (2009). Community organizing for stronger schools: Strategies and successes. Cambridge, MA: Harvard Education Press.

Merriam, S. B. (1998). Qualitative research and case study applications in education. San Francisco, CA: Jossey-Bass.

Miles, M.B. \& Huberman, A.M. (1994). Qualitative data analysis: an expanded sourcebook. Thousand Oaks, CA: Sage Publications.

Oakes, J., \& Rogers, J. (2006). Learning power: Organizing for education and justice. New York, NY: Teachers College Press.

Olivos, E.M. (2007). The power of parents: A critical perspective of bicultural parent involvement in schools. New York, NY: Peter Lang Publishing.

Payne, C. M. (2008). So much reform, so little change. Cambridge, MA: Harvard University Press.

Phelan, P., Davidson, A.L., \& Cao, H.T. (1991). Students' multiple worlds: Negotiating the boundaries of family, peer, and school cultures. Anthropology \& Education Quarterly, 22(3), 224-250.

Polletta, F. (2002). Freedom is an endless meeting: Democracy in American social movements. Chicago, IL: University of Chicago Press.

Ravitch, D. (2010). The death and life of the great American school system: How testing and choice are undermining education. New York, NY: Basic Books.

Rose, F. (2000). Coalitions across the class divide: Lessons from the labor, peace, and environmental movements. Ithaca, NY: Cornell University Press.

Rossman, G. B. \& Rallis, S. F., (2003). Learning in the field ( $2^{\text {nd }}$. ed.) Thousand Oaks, CA: Sage Publications.

Rogers, J. (2006). Forces of accountability? The power of poor parents in NCLB. Harvard Educational Review, 76(4), 611-641. 
Schutz, A. (2006). Home is a prison in the global city: The tragic failure of school-based community engagement strategies. Review of Educational Research, 76(4), 691-743.

Shirley, D. (1997). Community organizing for urban school reform. Austin, TX: University of Texas Press.

Shirley, D. \& Evans, M. P. (2007). Community organizing and No Child Left Behind. In M. Orr (Ed.), Transforming the city: Community organizing and the challenge of political change (pp. 109-133). Lawrence, KS: University of Kansas Press.

Stake, R. E. (2002). Case studies. In N. K. Denzin \& Y. S. Lincoln (Eds.), Handbook of qualitative research (pp. 435-454). Thousand Oaks, CA: Sage Publications.

Suarez-Orozco, C. \& Suarez-Orozco, M. M. (2001). Children of immigration. Cambridge, MA: Harvard University Press.

Tocqueville, A. (1835/2003). Democracy in America (I. Kramnickm, Trans.). New York, NY: Penguin Books.

U.S. Department of Education. (2003). No child left behind: A parents guide. Washington, DC: Office of the Secretary, Office of Public Affairs.

Valdes, G. (1996). Con respeto: Bridging the distance between culturally diverse families and schools. New York, NY: Teachers College Press.

Waller, W. (1932). The sociology of teaching. New York, NY: John Wiley \& Sons, Inc.

Warren, M. (2001). Dry bones rattling: Community building to revitalize American democracy. Princeton, NJ: Princeton University Press.

Warren, M. R. (2005). Communities and schools: A new view of urban educational reform. Harvard Educational Review, 75, 133-173.

Zarate, M.E. (2007). Understanding Latino parental involvement in education: Perceptions, expectations, and recommendations. Los Angeles, CA: The Tomás Rivera Policy Institute 